\title{
The Role of Classroom Behavior Management in Enhancing Student Emotional Intelïgence
}

\author{
Munawir Yusufa ${ }^{a}$, Sasmoko ${ }^{b}$ \\ ${ }^{a}$ Univeristas Sebelas Maret, Solo, Indonesia \\ ${ }^{b}$ Bina Nusantara University, Jakarta, Indonesia \\ Corresponding e-mail: amunawir_uns@yahoo.co.id
}

\begin{abstract}
Currently, many students are facing social-emotional problems so it takes an effort to improve students' emotional intelligence. One of the efforts that can be done by a school is through classroom behavioral management. This study aims to see the role of classroom behavioral management in improving students' emotional intelligence. The study population is all junior high school students in Jakarta. The sample is 147 students. The research method using Neuroresearch method is mixed methods between quantitative and qualitative research. Instrument calibration is constructed validity with RASCH MODEL approach. The result of the research shows that the influence of classroom behavioral management on the emotional intelligence of the students and the realization of the main behavioral management classroom is caused by "teacher who often praises the students" and "teachers who are able to understand students' difficulties" together.
\end{abstract}

Keywords: Classroom Behavioral Management, Emotional Intelligence

\section{INTRODUCTION}

Emotional intelligence is an interesting concept in various psychological studies and has been implemented in many fields, one of which is education. As an important theoretical construct, emotional intelligence has the potential to enable individuals to better solve problems so as to contribute to one's mental health (Por, Barriball, Fitzpatrick, \& Roberts, 2011).

Emotional intelligence is defined as a hypothesized set of skills to contribute to accurate judgments and expressions, effective emotional attributes and the use of feelings to motivate, plan and achieve achievements in one's life (Salovey \& Mayer, 1990). Emotional intelligence focuses on how a person regulates emotion, feels the emotion and understands the emotion itself so that emotional intelligence can involve the ability to make accurate reasoning about emotions and the ability to use emotions to improve thinking (Joseph \& Newman, 2010; Mayer, Roberts \& Barsade, 2008). This is because a person's emotions have a function that affects the integration of thought and behavior based on the information received so that it can be managed effectively (Brackett, 2011).

In today's era, many students face problems related to social-emotional aspects so as to have an effect on their academic and happiness (Zins \& Elias, 2003). Some individuals have a greater capacity to perform emotion processing as a guide for thinking and behaving. Someone who has high emotional intelligence will be better able to recognize and anticipate the emotional consequences of various events (Mayer, Salovey, \& Caruso, 2008). Impact and relevance of emotions is a combination of subjective nature and emotional experience (Petrides, Pita, \& Kokkinaki, 2007). One study found that a group of adolescents thought that when they were able to manage emotions well, it would tend to minimize physical depression and pain (Mavroveli, Petrides, Rieffe, \& Bakker, 2007) and it was suggested that students' emotional factors were closely related to Student success both academically and psychologically (Saklofske, Austin, Mastoras, Beaton, \& Osborne, 2012). Various literature shows the importance of emotional intelligence in the students so it is worthy to be studied further.

The emotional intelligence of students is closely related to each process of learning so that the teacher becomes one of the figures that can create conditions conducive to the emotional intelligence of students. Positive emotional situations can develop healthy relationships and support student learning that can be formed through effective classroom management (Jennings \& Greenberg, 
2009). Various components of the approach to classroom management have been documented in various literature through both observational and experimental studies (Oliver \& Reschly, 2010). Effective classroom management is a prevention of any maladaptive behavior that may develop. In general, classroom management practices are identified through the effectiveness of teacher behavior so as to shape effective student behavior changes (Oliver, Wehby, \& Reschly, 2011).

To achieve student achievement academically, it takes skills in managing the class. Classroom behavior management is used as a way to discipline and manage/control student behavior. Classroom behavior management is a complex set of skills that not only influence and control student behavior, but there is still an overall impression of discipline (Allen, 2010). If classroom behavior is not effectively managed, it indicates that learning programs have weaknesses in which students are less able to be identified inaccurately and lack support (Oliver \& Reschly, 2010).

Classroom behavioral management practices may include classroom physical arrangements, classroom structure, instructional management, procedures designed to improve appropriate behavior and procedures designed to reduce inappropriate behavior (Simonsen, Fairbanks, Briesch, \& Myers, 2008). With this emphasis, the classroom behavior management is not only related to academic issues or cognitive aspects of the students but also non-academic issues that are affective aspects of the students because teachers must ensure the integrity of preventive and corrective practices and feedback (Oliver \& Reschly, 2007). One study stated that in classroom behavioral management, teachers should also be able to maintain a positive climate in the classroom so that students can demonstrate effective behavior ( $\mathrm{Li}$ Grining et al., 2010). Nevertheless, no studies have attempted to examine in detail the relevance of classroom behavioral management with students' emotional intelligence. Therefore this study aims to examine how the role of classroom behavioral management in improving the emotional intelligence of students.

\section{RESEARCH METHOD}

The research method for this research use method of Neuroresearch. Neuroresearch is one of the research methods of a mix (mix methods) between qualitative and quantitative. Qualitative research methods (exploratory) and quantitative research methods (explanatory and confirmatory) (Fios, Sasmoko, \& Gea, 2016; Sasmoko \& Anggriyani, 2016; Sasmoko \& Ying, 2015)

Techniques of collecting variable data emotional intelligence $(\mathrm{Y})$ and classroom behavioral management $(\mathrm{X})$ with Likert scale questionnaire scaled ordinal. In this study, all field data was changed to equal interval scale by RASCH MODEL technique (Bartholomeu, Silva, \& Montiel, 2016; Curtis \& Boman, 2007). The study population is all junior high school students in Jakarta. The sample is 147 students. The experimental test of the research instrument used a sample of 60 students at random. Instrument calibration is constructed validity with RASCH MODEL approach. Rash model is a model of calculation analysis where item parameters can be estimated independently of the characteristics of sample calibration parameters (Goh, Marais, \& and Ireland Michael James, 2015; Habibi, Sarafrazi, \& Izadyar, 2014; Karabatsos, 2001)

The decision to examine validly and drop points is based on 3 (three) aspects: (a) outlier-sensitive fit of mean-square fit statistic between 0.5 to 1.5 ; (B) standardize fit statistic that is test $(\mathrm{t})$ for fit fit data with model equal to $-1,9 \mathrm{~s} / \mathrm{d}+1,9$; And (c) the point of correlation ( $\mathrm{Pt}$ Mean Corr) value of 0.4 to 0.85 (Kim \& Hong, 2004; Lewandowski, Co-investigator, \& Lewandowski, 2015; Masters, 1982). Based on the calculation of the construct validity of the instrument of emotional intelligence (Y), of 29 items planned, it turns out 15 points in the drop. So the valid instrument to measure the emotional intelligence $(\mathrm{Y})$ variable in this study only uses 14 items with the reliability index of 0.88 . Medium construct validity is classroom behavioral management instrument (X), of 15 items planned, it turns 8 points in the drop. So the valid instrument to measure the classroom behavioral management (X) variable in this study uses only 7 items with the reliability index of 0.76 .

\section{RESULT AND DISCUSSION}

\subsection{Result}

Before testing the research hypothesis first tested 2 (two) requirements analysis is the test of normality and linearity.

First, the data normality test of 2 research variables is emotionally intelligence and classroom behavioral management class is calculated by Proportion Estimation through Blom formula with P-P Plot approach (Figures 1 and 2). The P-P plot approach was taken because the sample size was $<200$ persons. Based on the calculation of Normal P- 
P Plot each data from both variables, it appears that all data distribution shows normal, that is the distribution of data tends to lead to the normal line, and the data distribution has no outlier. Likewise, when viewed from the Detrended Normal P-P Plot, the data distribution does not represent a sinus or cosine curve. So it can be concluded that the data of both variables have a normal distribution.
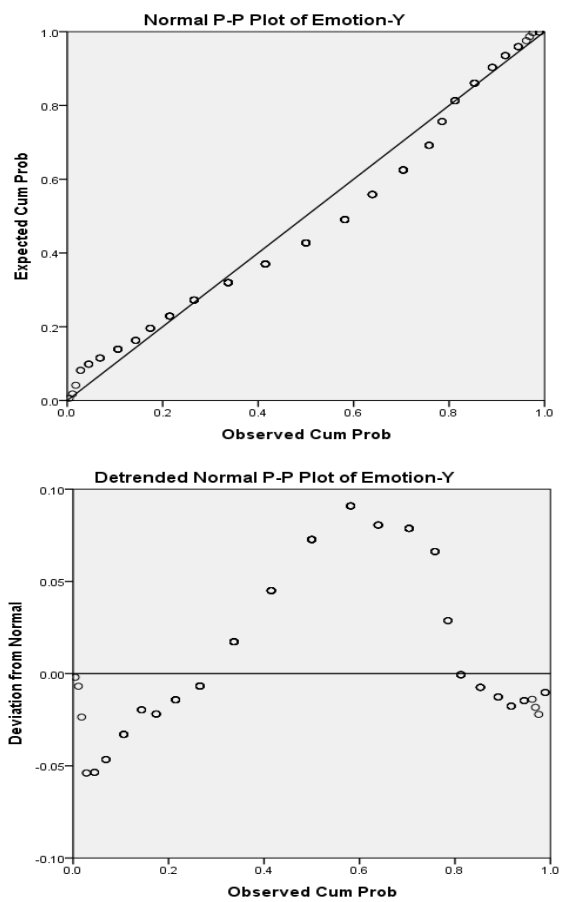

Figure 1. Data Normality Test of Variable Emotionally Intelligence
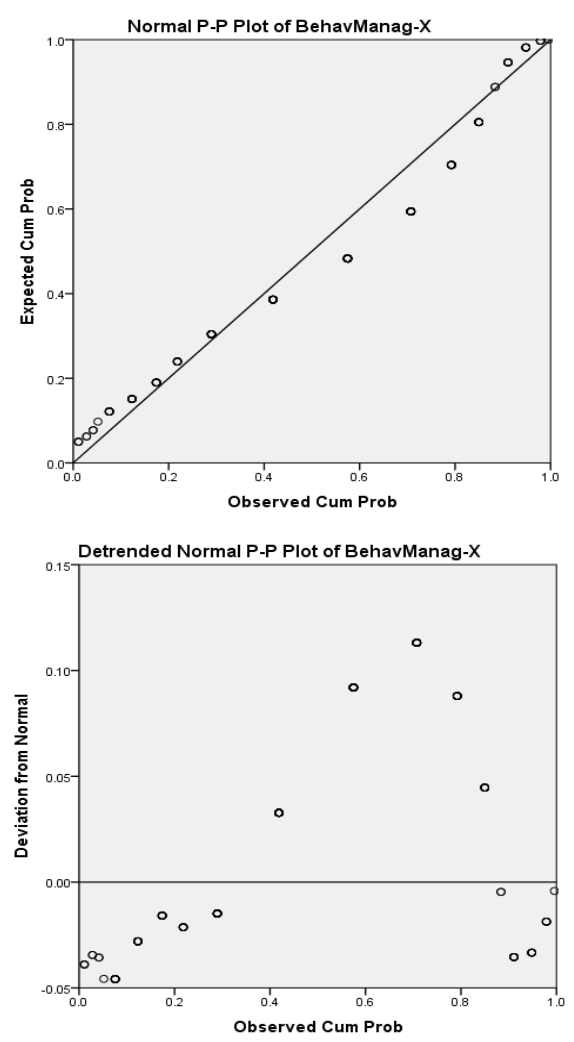

Figure 2. Data Normality Test of Classroom Behavior Management Variables

Second, linearity test (Table 1 ) is calculated by deviation from linearity test of classroom behavioral management variable $(\mathrm{X})$ as independent variable to emotional intelligence $(\mathrm{Y})$ variable as a dependent is generated $\mathrm{F}$ equal to 1,155 and significance value 0,311 is non-significant at $\alpha>0$, 05. So the line relationship between classroom variable behavioral management $(\mathrm{X})$ as an independent variable to emotional intelligence (Y) variable is linear.

The results of the first study, researchers set 3 (three) categories of emotional intelligence level students are students: (a) have a low emotional intelligence, (b) have a moderate emotional intelligence, and (c) have a high emotional intelligence. Data analysis (Table 2) is done with a confidence interval at 5\% significance level and produced lower and upper bound between 1.0778 up to 1.3636. Based on these results, it can be concluded that junior high school students in Jakarta tend to have a significant emotional intelligence at $\alpha$ $<0.05$. 
Table 2. First Hypothesis Test

\begin{tabular}{|c|c|c|c|c|}
\hline \multicolumn{5}{|c|}{ Descriptives } \\
\hline & & & Statistic & Std. Error \\
\hline \multirow[t]{13}{*}{ Emotion-Y } & Mean & & 1.2207 & .07230 \\
\hline & \multirow{2}{*}{$\begin{array}{l}95 \% \text { Confidence Interval } \\
\text { for Mean }\end{array}$} & Lower Bound & 1.0778 & \\
\hline & & Upper Bound & 1.3636 & \\
\hline & $5 \%$ Trimmed Mean & & 1.1766 & \\
\hline & Median & & 1.0600 & \\
\hline & Variance & & .768 & \\
\hline & Std. Deviation & & .87662 & \\
\hline & Minimum & & -.97 & \\
\hline & Maximum & & 3.98 & \\
\hline & Range & & 4.95 & \\
\hline & Interquartile Range & & .97 & \\
\hline & Skewness & & .844 & .200 \\
\hline & Kurtosis & & 1.156 & .397 \\
\hline
\end{tabular}

The second research result, the researcher determined 5 (five) categories of the students 'level of assessment on behavior management in the classroom: (a) the students considered that the teacher is not very good at managing the students' behavior in the class, (b) the students think that the teacher is not good in managing (D) students judge that teachers are good at managing students' behavior in the classroom, and (e) students judge that teachers are very good at managing student behaviors in the classroom. Data analysis (Table 3) was conducted with a confidence interval at 5\% significance level and produced lower and upper boundary between 1.4195 up to 1.8021. Based on these results, it can be concluded that junior high school students in Jakarta tend to judge that teachers are not good in managing student behavior in the class significantly on $\alpha<0.05$.

Table 3. Second Hypothesis Test

\begin{tabular}{|c|c|c|c|c|}
\hline \multicolumn{5}{|c|}{ ives } \\
\hline & & & Statistic & Std. Error \\
\hline \multirow[t]{13}{*}{ BehavManag-X } & Mean & & 1.6108 & .09679 \\
\hline & \multirow{2}{*}{$\begin{array}{l}95 \% \text { Confidence Interval } \\
\text { for Mean }\end{array}$} & Lower Bound & 1.4195 & \\
\hline & & Upper Bound & 1.8021 & \\
\hline & $5 \%$ Trimmed Mean & & 1.5335 & \\
\hline & Median & & 1.5600 & \\
\hline & Variance & & 1.377 & \\
\hline & Std. Deviation & & 1.17357 & \\
\hline & Minimum & & -.32 & \\
\hline & Maximum & & 6.20 & \\
\hline & Range & & 6.52 & \\
\hline & Interquartile Range & & .88 & \\
\hline & Skewness & & 1.196 & .200 \\
\hline & Kurtosis & & 1.909 & .397 \\
\hline
\end{tabular}

The result of the third study (Table 4) shows that the analysis of the relationship between the classroom behavioral management $(\mathrm{X})$ and emotional intelligence $(\mathrm{Y})$ ie ryx of 0.421 is positively related. Determination of variance that describes the closeness of the relationship between classroom behavioral management (X) with emotional intelligence $(\mathrm{Y})$ of 0.172 . This means that the contribution of classroom behavioral management $(\mathrm{X})$ to emotional intelligence $(\mathrm{Y})$ is $17.2 \%$, while the condition in the population depicted by t result of 5,588 is very significant at $\alpha$ $<0,01$. So the relationship between classroom behavioral management (X) with emotional intelligence (Y) in the population is also positive and its contribution to form emotional intelligence of $17.2 \%$. The linear regression line equation in sample classroom behavioral management $(\mathrm{X})$ on emotional intelligence $(\mathrm{Y})$ is depicted by $\hat{\mathrm{Y}}=0,314 \mathrm{X}$. That is, the emotional intelligence of junior high school students in Jakarta can be changed twice from the current condition only if the school intervenes the program at least as much as 7 (seven) times priority program. So it can be concluded that the students' assessment of teacher management on the behavior of students in the classroom which was then given the classroom behavioral management (X) on emotional intelligence $(\mathrm{Y})$ is proven.

All three of the above studies are then explored again with the Binary Segmentation analysis approach called Classification and Regression Trees. In this analysis, the researchers set the Prunning of Depth by 2, Parent 2, and Child by 1 , with significance level $\alpha<0,05$. The result is like picture 3 below.

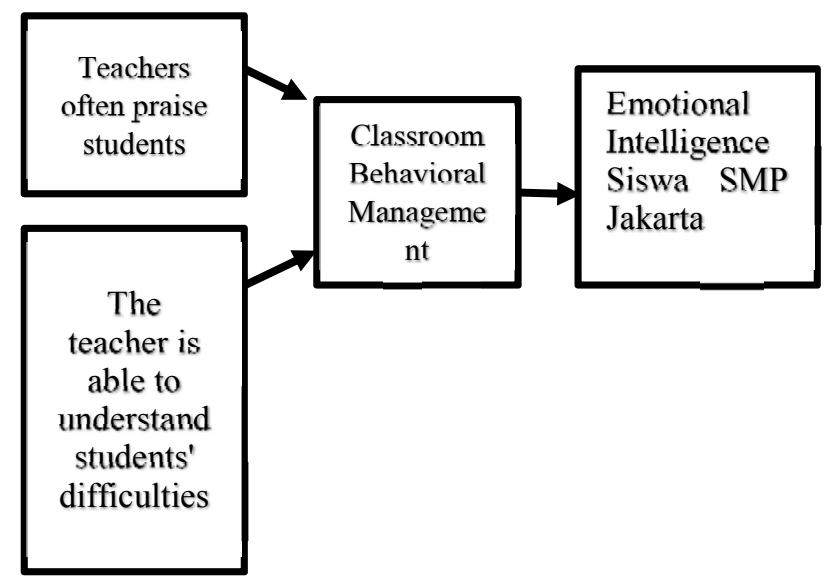

Figure 3. Most Dominant Determinants of Classroom Behavior Management

Based on the result, Figure 3 found that the realization of the main behavioral management classroom is caused by "teachers who often praise students" and "teachers who are able to understand students' difficulties" simultaneously.It was found also found that: (a) 15th graders had higher 
emotional intelligence than grade 13 or grade 14 students at $\alpha<0,05$; (B) grade 15 students assess that teachers are better able to manage student behavior in the class than 13th and 14th graders are significantly significant at $\alpha<0.01$; (C) Both male and female students are equally likely to have moderate emotional intelligence and also equally judge that the teacher is not good at managing student behavior in the class significantly at $\alpha<0.05$.

\subsection{Discussion}

Simply put, one's emotional and social capacity is the ability to recognize and manage emotions so as to solve problems effectively and build positive relationships with others (Zins \& Elias, 2003). This capacity is important to be owned by students so it is necessary to make various efforts to improve the capacity which is summarized in terms of emotional intelligence. The results showed that classroom behavioral management was able to improve students 'emotional intelligence with the main supporting factors that teachers praised students and teachers for understanding students' difficulties. Therefore, it is needed teacher's effort to build a positive learning climate that can help students feel emotionally and psychologically comfortable. Proper treatment will minimize the emergence of negative emotions that will eventually lead to the emergence of inappropriate behavior (Emmer \& Stough, 2001).

Managing behavior in the classroom is not easy. But this effort needs to be done. School leaders should also ensure professional development related to classroom organization and behavior management (Emmer \& Stough, 2001).

\section{REFERENCES}

[1] Allen, K.P. (2010). Classroom Management, Bullying, and Teacher Practices, 34(1)

[2] Bartholomeu, D., Silva, M. C. R., \& Montiel, J. M. (2016). Improving the Likert Scale of the Children's Social Skills Test by Means of Rasch Model. Psychology, 7(June), 820-828.

[3] Brackett, M. A. et al. (2011). Emotional Intelligence: Impications for Personal, Social, Academic, and Workplace Success. Sosial and Personalty Psychology Compass, 5(1), 88103.

[4] Curtis, D. D., \& Boman, P. (2007). X-ray your data with Rasch. International Education Journal, 8(2), 249-259.
[5] Emmer, E. T., \& Stough, L. M. (2001). Classroom Management: A Critical Part of Educational Psychology, With Implications for Teacher Education, 36(2), 103-112.

[6] Fios, F., Sasmoko, \& Gea, A. A. (2016). Neuro-Research Method: A Synthesis Between Hermeneutics and Positivism. Advanced Science Letters, 22(9), 2202-2206. https://doi.org/10.1166/asl.2016.7565

[7] Goh, H. E., Marais, I., \& and Ireland Michael James. (2015). A Rasch Model Analysis of the Mindful Attention Awareness Scale. Assessment, (October), 1-12. https://doi.org/10.1177/1073191115607043

[8] Habibi, A., Sarafrazi, A., \& Izadyar, S. (2014). Delphi Technique Theoretical Framework in Qualitative Research. The International Journal Of Engineering And Science, 23191813. https://doi.org/10.1016/S01692070(99)00018-7

[9] Jennings, P. a., \& Greenberg, M. T. (2009). The Prosocial Classroom: Teacher Social and Emotional Competence in Relation to Student and Classroom Outcomes. Review of Educational Research, 79(1), 491-525. https://doi.org/10.3102/0034654308325693

[10] Joseph, D. L., \& Newman, D. A. (2010). Emotional intelligence: An integrative metaanalysis and cascading model. Journal of Applied Psychology, 95(1), 54-78. https://doi.org/10.1037/a0017286

[11] Karabatsos, G. (2001). The Rasch model, additive conjoint measurement, and new models of probabilistic measurement theory. Journal of Applied Measurement, 2(4), 389423.

[12] Kim, B. S. K., \& Hong, S. (2004). A Psychometric Revision of the Asian Values Scale Using the Rasch Model. Measurement and Evaluation in Counseling and Development, 37(1), 15-27. https://doi.org/10.1016/j.biocon .2013.11.034

[13] Lewandowski, C. M., Co-investigator, N., \& Lewandowski, C. M. (2015). Self-directed Learning Oriented Assessments in the AsiaPasific. The Effects of Brief Mindfulness Intervention on Acute Pain Experience: An Examination of Individual Difference, 1, 16891699. 1017/CBO9781107415324.004 https://doi.org/10.

[14] Li Grining, C., Raver, C. C., Champion, K., Sardin, L., Metzger, M., \& Jones, S. M. (2010). Understanding and Improving Classroom Emotional Climate and Behavior 
Management in the "Real World": The Role of Head Start Teachers' Psychosocial Stressors. Early Education \& Development, 21(1), 6594. https://doi.org/10.1080/10409280902783509

[15] Masters, G. N. (1982). A Rasch model for partial credit scoring. Psychometrika, 47(2), 149-174. https://doi.org/10.1007/BF02296272

[16] Mavroveli, S., Petrides, K. V., Rieffe, C., \& Bakker, F. (2007). Trait emotional intelligence, psychological well-being and peer-rated social competence in adolescence. British Journal of Developmental Psychology, 25(2), 263-275. https://doi.org/10.1348/026151006X118577

[17] Mayer, J. D., Roberts, R. D., \& Barsade, S. G. (2008). Human Abilities: Emotional Intelligence. Annual Review of Psychology, 59(1), 507-536. https://doi.org/10.1146/annurev.psych.59.1030 06.093646

[18] Mayer, J. D., Salovey, P., \& Caruso, D. R. (2008). Emotional intelligence: New ability or eclectic traits? American Psychologist, 63(6), 503-517. https://doi.org/10.1037/0003066X.63.6.503

[19] Oliver, R. M., \& Reschly, D. J. (2007). Effective Classroom Management: Teacher Preparation and Professional Development. National Comprehensive Center for Teacher Quality, 1-24. Retrieved from http://tqcenter.learningpt.org/topics/effectiveCl assroomManagement.pdf

[20] Oliver, R. M., \& Reschly, D. J. (2010). Special education teacher preparation in classroom management: Implications for students with emotional and behavioral disorders. Behavioral Disorders, 35(3), 188-199. https://doi.org/10.1126/science.139.3555.660

[21] Oliver, R. M., Wehby, J. H., \& Reschly, D. J. (2011). Teacher Classroom Management Practices: Effects on Disruptive or Aggressive Student Behavior. Society for Research on Educational Effectiveness, 1. https://doi.org/10.1017/CBO9781107415324.0 04

[22] Petrides, K. V., Pita, R., \& Kokkinaki, F. (2007). The location of trait emotional intelligence in personality factor space. British Journal of Psychology, 98(2), 273-289. https://doi.org/10.1348/000712606X120618

[23] Por, J., Barriball, L., Fitzpatrick, J., \& Roberts, J. (2011). Emotional intelligence: Its relationship to stress, coping, well-being and professional performance in nursing students.
Nurse Education Today, 31(8), 855-860. https://doi.org/10.1016/j.nedt.2010.12.023

[24] Saklofske, D. H., Austin, E. J., Mastoras, S. M., Beaton, L., \& Osborne, S. E. (2012). Relationships of personality, affect, emotional intelligence and coping with student stress and academic success: Different patterns of association for stress and success. Learning and Individual Differences, 22(2), 251-257. https://doi.org/10.1016/j.lindif.2011.02.010

[25] Salovey, P., \& Mayer, J. D. (1990). Emotional Intelligence. Imagination, Cognition and Personality, 9, 185-211. https://doi.org/10.1016/S0962-1849(05)800587

[26] Sasmoko, \& Anggriyani, D. (2016). Neuroresearch (A Model of Research Method). In A. Khan, M. N. A. Ghafar, A. R. Hamdan, \& R. Talib (Eds.), Research on Educational Studies (2016th ed., pp. 33-45). New Delhi: Serial Publications PVT. LTD.

[27] Sasmoko, \& Ying, Y. (2015). Construct Validity in NeuroResearch. Advanced Science Letters, 21(7), 2438-2441. https://doi.org/ doi:10.1166/asl.2015.6301

[28] Simonsen, B., Fairbanks, S., Briesch, A., \& Myers, D. (2008). Evidence-based Practices in Classroom Management: Considerations for Research to Practice. Education and Treatment of Children, 31(1), 351-380. https://doi.org/10.1353/etc.0.0007

[29] Zins, J. E., \& Elias, M. J. (2003). Social and Emotional Learning, (1995). 
Table 1. Linearity Test of Line Relationship Emotional Intelligence with Classroom Behavioral Management

ANOVA Table

\begin{tabular}{|c|c|c|c|c|c|c|c|}
\hline & & & $\begin{array}{l}\text { Sum of } \\
\text { Squares }\end{array}$ & df & Mean Square & $\mathrm{F}$ & Sig. \\
\hline \multirow{5}{*}{$\begin{array}{l}\text { Emotion-Y* } \\
\text { BehavManag-X }\end{array}$} & \multirow[t]{3}{*}{ Between Groups } & (Combined) & 32.152 & 18 & 1.786 & 2.856 & .000 \\
\hline & & Linearity & 19.878 & 1 & 19.878 & 31.788 & .000 \\
\hline & & Deviation from Linearity & 12.274 & 17 & .722 & 1.155 & .311 \\
\hline & \multicolumn{2}{|l|}{ Within Groups } & 80.043 & 128 & .625 & & \\
\hline & \multicolumn{2}{|l|}{ Total } & 112.195 & 146 & & & \\
\hline
\end{tabular}

Table 4. Third Hypothesis Test

Model Summary

\begin{tabular}{|l|c|r|r|r|}
\hline Model & R & R Square & $\begin{array}{c}\text { Adjusted R } \\
\text { Square }\end{array}$ & $\begin{array}{c}\text { Std. Error of } \\
\text { the Estimate }\end{array}$ \\
\hline 1 & $.421^{\mathrm{a}}$ & .177 & .172 & .79792 \\
\hline
\end{tabular}

a. Predictors: (Constant), BehavManag- $X$

ANOVA $^{a}$

\begin{tabular}{|ll|r|r|r|r|r|}
\hline \multicolumn{2}{|c|}{} & \multicolumn{1}{c|}{$\begin{array}{c}\text { Sum of } \\
\text { Squares }\end{array}$} & \multicolumn{1}{c|}{$\mathrm{df}$} & Mean Square & \multicolumn{1}{c|}{$\mathrm{F}$} & \multicolumn{1}{c|}{ Sig. } \\
\hline 1 & Regression & 19.878 & 1 & 19.878 & 31.222 & $.000^{\mathrm{b}}$ \\
& Residual & 92.317 & 145 & .637 & & \\
& Total & 112.195 & 146 & & & \\
\hline
\end{tabular}

a. Dependent Variable: Emotion-Y

b. Predictors: (Constant), BehavManag- $X$

Coefficients $^{\mathrm{a}}$

\begin{tabular}{|c|c|c|c|c|c|c|}
\hline \multirow{2}{*}{\multicolumn{2}{|c|}{ Model }} & \multicolumn{2}{|c|}{ Unstandardized Coefficients } & \multirow{2}{*}{$\begin{array}{c}\text { Standardized } \\
\text { Coefficients }\end{array}$} & \multirow[b]{2}{*}{$t$} & \multirow[b]{2}{*}{ Sig. } \\
\hline & & $\mathrm{B}$ & Std. Error & & & \\
\hline \multirow[t]{2}{*}{1} & (Constant) & .714 & .112 & & 6.376 & .000 \\
\hline & BehavManag-X & .314 & .056 & .421 & 5.588 & .000 \\
\hline
\end{tabular}

a. Dependent Variable: Emotion-Y 